\title{
Uptake of Efficient Marketing Strategies among Footwear and Textile Entrepreneurs in Alexandra Township
}

\author{
Yohannes Worku, Mammo Muchie \\ Tshwane University of Technology (TUT), Nana Sita Street, Pretoria, South Africa \\ Johannes.Worku@gmail.com
}

\begin{abstract}
One of the priority needs of Small, Micro and Medium-Sized Enterprises (SMMEs) that operate in Alexandra Township is to adopt effective marketing strategies that are recommended by Mooradian, Matzler and Ring (2012) and Kotler and Keller (2012), in which emphasis is placed on setting the right selling price of products, offering the right product, utilising the right promotion strategies for products, and rendering services to customers at the right place. Information needed for the survey was gathered from 108 operators of SMMEs in Alexandra Township. Ordered logit and Bayesian methods were used for estimating predictors of effective marketing. The study found that 63 of the 108 respondents who were selected for the study (58\%) possessed adequate marketing skills and capabilities, whereas the remaining 45 respondents $(42.23 \%)$ were incapable of marketing their goods and services effectively. Results obtained from logit and Bayesian analysis showed that 3 factors affected the ability to market goods and services effectively (access to credit facility for ordering stock, access to loan from money-lending institutions, and ability to network with wholesale suppliers and retailers).
\end{abstract}

Keywords: Alexandra Township, Footwear and textile, SMMEs, Marketing, Logit analysis

\section{Introduction and Background to Study}

According to Statistics South Africa (2012), Alexandra Township was established in 1912, and is one of the oldest South African townships in Gauteng Province. In addition to fairly well-built dwelling units, Alexandra consists of more than 20, 000 informal dwellings. Alexandra shares boundary with Wynberg, Marlboro, Kelvin, Kew, Lombardy West and Lombardy East. Alexandra Township is situated on the banks the Jukskei River, and is home to mostly low-income households. Since the early 1990s, Alexandra Township has been growing rapidly in terms of entrepreneurial activities, and has attracted a large number of viable small, micro and medium-sized enterprises (SMMEs) in all sectors of the economy. Based on the 2011 census carried out by Statistics South Africa (2012) in 2011, the total population of Alexandra Township is about 180, 000. Most of the residents of Alexandra Township are Black African (99\%). The most commonly spoken languages at Alexandra Township are Zulu (26.3\%), Northern Sotho (23.1\%), Tsonga (11.3\%), Xhosa (9.8\%) and English (29.6\%). Alexandra Township is home to a large number of textile and footwear enterprises that are owned and operated by local as well as migrant entrepreneurs. The rate of unemployment among the inhabitants of Alexandra Township is about 55\% (Gauteng Provincial Legislature, 2017). The main purpose of the study was to assess and evaluate the suitability of marketing tactics and strategies used by entrepreneurs in the footwear and textile sector of Alexandra Township.

The assessment was made based on indicators defined by Mooradian, Matzler and Ring (2012: 21-23) and Kotler and Keller (2012: 49-50) in which the authors have recommended the use of the principle of the four Ps in marketing (Price, Product, Promotion and Place). A good number of research studies have attempted to find answers that revolve around the kind of Business-Marketing tactics or short-term strategies that SMMEs have utilised to survive and be successful as Businesses. The key mandate of the South African National Department of Small Enterprises Development Agency (2012) is to equip South African youth with basic entrepreneurial skills with a particular emphasis on poorly skilled unemployed youth and low-income households in all nine South African provinces. Worku (2016) has reported that inappropriate marketing and entrepreneurial tactics are underlying causes of failure in South African start-up businesses. The author has identified grossly inappropriate and inadequate entrepreneurial skills as well as an inability to raise loans that are needed for business operations as key causes of failure. Marivate (2014) has reported that the educational curriculum used by South African academic institutions is not suitable for producing competent entrepreneurs. The author has pointed out that operators often do not know how to market their goods, 
products and services effectively. The study conducted by Ogunnaike and Olaleke (2010) has shown that the ability of entrepreneurs to market their products, goods and services effectively is essential for realising longterm survival and profitability.

The SMME sector contributes about 35\% to Gross Domestic Product (South African National Department of Small Enterprises Development Agency, 2012) by creating employment opportunities and livelihood for unemployed South Africans. Moraru (2012) has listed down the numerous positive contributions made by small businesses to local communities in Sub-Saharan African countries. One of the key contributions made by operators of SMMEs is the reduction of costs of goods, products and services. The other benefit is the provision of retail services over extended hours including long weekends and holidays. Narang (2012) has suggested that entrepreneurial skills can be promoted by way of amending the educational curriculum used at the high school level. Based on research conducted in the USSR, Racela (2014) has shown that SMMEs are vital for promoting the culture of fair competition and service quality at the marketplace. Akos-Rona and Sagi (2015) have shown that SMMEs play a critical role in building national economies and alleviating abject poverty among the masses, especially in Sub-Saharan African countries. Dagut (2017), Bernier (2015) and Jamali, Lund-Thomsen and Jeppesen (2017) have shown a host of developmental challenges faced routinely by SMMEs in all parts of Sub-Saharan Africa.

The major obstacles highlighted by the authors include chronic problems of underdevelopment, lack of infrastructure, lack of support from local municipalities, poor quality water, light and waste management services. Martinez and Martinez (2010) have pointed out that unfair tax assessment and unnecessary bureaucracy are two key causes of failure in start-up enterprises. Jurgens and Donaldson (2012) have found that South African townships such as Alexandra are characterised by poor municipal services, red tape and cumbersome bureaucracy. According to Akos-Rona and Sagi (2015), not enough is known about the ability of operators of textile and footwear operators in South African townships to market their products, goods and services efficiently to potential customers. Jutla, Bodorick and Dhaliwal (2012) have highlighted the numerous benefits of using modern methods of marketing by operators of SMMEs in developing nations. The goal of the survey was to make an original contribution to the literature on SMMEs in Alexandra Township by collecting fresh data from SMMEs in the footwear and textile sector of Alexandra Township.

\section{Literature Review}

Alexandra Township is one of the oldest South African townships in which black indigenous South African entrepreneurs operate footwear and textile SMMEs. The township provides livelihood to aspiring black South Africans in various economic sectors. The 2011 household survey conducted by Statistics South Africa (2012) indicates that Alexandra Township is characterised by low to middle-level income, unemployment, and poor municipal service delivery in comparison with other suburbs of Johannesburg. Stam (2015) has reported that failure in marketing strategies is a principal cause of failure and bankruptcy in start-up enterprises globally. Zineldine and Phillipson (2012) have pointed out that failure in implementing the 4P principle of marketing (Price, Product, Promotion and Place) is the key underlying cause of bankruptcy and loss of income in startup enterprises, especially in poorly developed communities such as Alexandra Township. A technical report published by Thompson (2016) indicates that poor marketing skills by entrepreneurs account for failure and bankruptcy in more than a third of all newly established South African SMMEs. Since the mid-1990s, cheap foreign textile and footwear products have been flooding the South African footwear and textile industry. This phenomenon has affected local footwear and textile producers in townships such as Alexandra.

Although there has been a call for protection by local producers, no significant restriction has been put in place in favour of local producers. South African producers have been calling for tangible protection and rescue measures from the South African Government since the early 1990s. However, local operators have not yet recovered from their losses. In this regard, South African trade unions in the textile and footwear industry have asked for Government protection in the form of quotas, levies, high duties, import tax and restriction. Callaghan and Venter (2011) have identified predictors of performance by local operators of SMMEs. The authors have found that poor marketing and networking skills are two key obstacles faced by 
local operators of SMMEs. Charman, Petersen, Piper, Liedeman and Legg (2017) have pointed out that inability to market effectively is a key cause of loss of income and profit in start-up SMMEs. Fatoki (2014) has reported that South African start-up SMMEs fail due to lack of entrepreneurial and marketing skills, poor networking skills, and difficulty in obtaining finance from formal money lending institutions. The author has recommended the roll out of tailor-made training and mentorship programmes.

Chimucheka (2014) has found that start-up SMMEs in the footwear and textile sector often struggle to secure loans that are needed for business operation. The author has pointed out that start-up SMMEs in the footwear and textile industry often fail to order large quantities of merchandise from wholesale suppliers due to difficulty in borrowing money from loan providers. SMMEs in the footwear and textile industry often fail due to the inability to order merchandise in bulk and poor entrepreneurial and networking skills (Worku, 2016). Marivate (2014) has recommended the provision of tailor-made training programmes to operators of startup SMMEs along with monitoring and evaluation programmes. According to Dagut (2017), intervention programmes undertaken by the South African Government have failed to result in tangible results. According to George, Corbishley, Khayesi, Haas and Tihanyi (2016), the failure rate among newly established SMMEs in Sub-Saharan African countries including South Africa is still high. Aparicio, Urbano and Audretsch (2016) have found that more than $50 \%$ of all newly established SMMEs fail before operating for three consecutive years.

Leigh and Blakely (2016) have recommended improved access to finance and the provision of tailor-made training programmes and monitoring and evaluation programmes to start-up SMMEs in Sub-Saharan African countries including South Africa. Although the South African Government has launched initiatives for supporting local SMMEs in the footwear and textile sector since the mid-1990s, the local sector has failed to compete favourably with foreign competitors due to a host of factors. Examples of such factors are inadequate marketing skills, lack of technical skills in manufacturing, lack of entrepreneurial skills, the high cost of labour, the high cost of production, lack of access to finance, poor infrastructure, lack of relevant skillsbased training programmes, and lack of monitoring and evaluation programmes. Kotler and Keller (2012) have outlined the importance of the four Ps for effective marketing. The four Ps entail efficiency in setting a selling price, offering the correct product to customers, the ability to promote the correct product by using appropriate means, and the ability of entrepreneurs to offer products and services at the correct place to customers. The study assesses and evaluates that ability of footwear and textile operators in Alexandra Township to apply the four Ps as recommended by Kotler and Keller (2012).

Training programmes that are offered to operators of SMMEs by the South African Government do not place emphasis on the merits of using the Four-P principle (the right product, the right selling price, the right promotion strategy, and the right place) of marketing goods and services to customers (Marivate, 2014). Very few studies have been conducted so far to assess and evaluate the degree to which marketing tactics and strategies used by operators of footwear and textile businesses in Alexandra Township are effective by the standards of Mooradian, Matzler and Ring (2012) and that of Kotler and Keller (2012). Reports published by Akos-Rona (2015) recommend appropriate remedial actions that are suitable for reducing failure rates in newly established SMMEs that are operated by entrepreneurs who lack entrepreneurial, marketing and managerial skills. The paper is a result of an original survey conducted by gathering valuable information from businesses in Alexandra Township. The available literature, by and large, dwells on the lack of entrepreneurial skills and challenges related to raising loans. This study aims to shed light on the importance of marketing skills to SMMEs in the footwear and textile industry of Alexandra Township.

Objectives of Study: The suitability of marketing tactics and strategies used by SMMEs in the footwear and textile sector of Alexandra Township is assessed as part of the study by the standards of Mooradian, Matzler and Ring (2012). The two secondary aims of the study are the following: To identify and quantify key predictors of effective marketing; and to identify key obstacles to sustained viability in the footwear and textile industry of Alexandra Township. 


\section{Method}

Sample Size of Study and Data Analyses: An exploratory research design was utilised in which business related information was obtained from 108 operators of footwear and textile businesses conducting business in Alexandra Township. The level of significance of the study was 5\%. The margin of error was 0.048 . The percentage of businesses that utilise appropriate marketing techniques and strategies in the course of conducting business operation was 55\%. Using these figures, a sample of size 108 was determined for the study. According to Chow, Shao, Wang and Lokhnygina (2017), both the sampling technique and sample size of the study are appropriate for the study. Data was collected from eligible respondents by using a structured, pretested and validated questionnaire of study. Validity was ensured by conducting a pilot study of size 5 business operators at Alexandra Township. Cronbach's Alpha test was used for ensuring reliability and internal consistency in measurement tools.

The outcome variable of study assesses how effectively SMMEs market their goods and services to potential customers and clients. Criteria developed by Mooradian, Matzler and Ring (2012:45) were used for measuring values of the dependent variable of study. The explanatory variables were various indicators of efficiency in marketing goods and services. The purpose of data analyses was to identify and quantify key predictors of effective marketing by operators of SMMEs. The main methods of data analyses were cross-tab analyses, logit analysis (Agresti, 2016) and Bayesian analysis (Kulkarni, 2016). Face validity (Lewis and Loewenthal, 2015) was used for ensuring validity. The Cronbach Alpha test (Kline (2015) was used for ensuring reliability and internal consistency. All estimated Cronbach Alpha coefficients had magnitudes of $75 \%$ or above.

\section{Results of Data Analyses}

Frequency tables were used for obtaining frequency counts and percentages for the various attributes of participants in the survey. One major finding of the research is that $62 \%$ of businesses were viable. The percentage of businesses that were not viable was 38\%. Eighty-five percent of entrepreneurs owned their businesses. Eighty-two percent of entrepreneurs were male, whereas the remaining $18 \%$ were female. Less than $2 \%$ of entrepreneurs had ages 25 years or less. About $25 \%$ of entrepreneurs had ages of 26 to 36 years. About $70 \%$ of entrepreneurs had ages of 37 to 57 years. Less than 3\% of entrepreneurs had ages of 58 years or more. At the time of the study, about $16 \%$ of entrepreneurs had been in business for a period of three years or less. About $35 \%$ of them had been in business for four to seven years. About $49 \%$ of them were in business for five years or more. About $17 \%$ of entrepreneurs had Grade 12 level education or less.

About $27 \%$ of them had post-matric certificates. About $21 \%$ of them had diplomas. About $35 \%$ of them had a Bachelor's degree or better academic qualifications. About $10 \%$ of entrepreneurs owned their business premises, whereas about $90 \%$ of them rented their business premises. The percentage of entrepreneurs who had taken one or more training sessions on how to operate businesses was $36 \%$, whereas $64 \%$ of entrepreneurs had never had such an opportunity. In the past, $36 \%$ of entrepreneurs had succeeded in obtaining one or more loans, whereas $64 \%$ of them have had no such luck in the past. At the time of the study, about $10 \%$ of entrepreneurs had business plans, whereas the remaining $90 \%$ had no business plans. These results are fairly similar to those reported by Fatoki (2014), Marivate (2014) and Worku (2016) about startup SMMEs conducting business in South African townships and cities. 
Table 1: Profile of Entrepreneurs $(n=108)$

\begin{tabular}{|c|c|}
\hline Characteristic & Number of respondents and percentage \\
\hline Viability of businesses & $\begin{array}{l}\text { Viable: } 67(62.04 \%) \\
\text { Not viable: } 41(37.96 \%)\end{array}$ \\
\hline Ownership status of business operator & $\begin{array}{l}\text { Owner: } 92(85.19 \%) \\
\text { Employee: } 16(14.81 \%)\end{array}$ \\
\hline Gender of business operator & $\begin{array}{l}\text { Male: } 89(82.41 \%) \\
\text { Female: } 19(17.59 \%)\end{array}$ \\
\hline Age category in years & $\begin{array}{l}25 \text { years or less: } 2(1.85 \%) \\
26 \text { to } 36 \text { years: } 27(25.00 \%) \\
37 \text { to } 57 \text { years: } 76(70.37 \%) \\
58 \text { years or more: } 3(2.78 \%)\end{array}$ \\
\hline Duration of operation of business & $\begin{array}{l}\text { Three years or less: } 17(15.74 \%) \\
\text { Four to seven years: } 38(35.19 \%) \\
\text { Five years or more: } 53(49.07 \%)\end{array}$ \\
\hline Highest level of education & $\begin{array}{l}\text { Grade } 12 \text { or less: } 18(16.67 \%) \\
\text { Post-matric certificate: } 29(26.85 \%) \\
\text { Diploma: } 23(21.30 \%) \\
\text { Bachelor's degree or more: } 38(35.19 \%)\end{array}$ \\
\hline Renting business premises & $\begin{array}{l}\text { Yes: } 97(89.81 \%) \\
\text { No: } 11(10.19 \%)\end{array}$ \\
\hline One or more training opportunity & $\begin{array}{l}\text { Yes: } 39(36.11 \%) \\
\text { No: } 69(63.89 \%)\end{array}$ \\
\hline $\begin{array}{l}\text { Past experience of at least one } \mathrm{s} \\
\text { application for a loan }\end{array}$ & $\begin{array}{l}\text { lYes: } 39(36.11 \%) \\
\text { No: } 69(63.89 \%)\end{array}$ \\
\hline Business plan available & $\begin{array}{l}\text { Yes: } 11(10.19 \%) \\
\text { No: } 97(89.81 \%)\end{array}$ \\
\hline Average monthly income of the busines & $\begin{array}{l}\text { R25, } 000 \text { or less: } 54(45.00 \%) \\
\text { R25, } 001 \text { to R50, } 000: 39(32.50 \%) \\
\text { R50, } 001 \text { to R100, } 000: 15(12.50 \%) \\
\text { R100, } 001 \text { or more: } 12(10.00 \%)\end{array}$ \\
\hline
\end{tabular}

Table 2 shows frequency counts and percentages for the source of start-up capital and average monthly income of the 108 entrepreneurs in the survey. Seventy-three percent of entrepreneurs raised their start-up capital from family members or their own personal savings, whereas about $27 \%$ of them raised their start-up capital from formal money-lending institutions such as commercial banks or microfinance institutions by taking loans. About 31\% of entrepreneurs had a monthly average income of R25, 001 to R50, 000 . About 35\% of entrepreneurs promoted items on sale by using word-of-mouth. The results reported in Table 1 are fairly similar to results that have been reported by Fatoki (2014) and Akos-Rona and Sagi (2015) about start-up enterprises in Sub-Saharan African countries including South Africa. 
Table 2: Source of Start-Up Capital and Marketing Strategies ( $n=108)$

\begin{tabular}{ll}
\hline Characteristic & Number of respondents and percentage \\
\hline Source of start-up capital & Family or personal savings: $79(73.15 \%)$ \\
& Loan: $29(26.85 \%)$ \\
& R25, 000 or less: $49(45.37 \%)$ \\
Average monthly income of business in Rand & R25, 001 to R50, 000: $34(31.48 \%)$ \\
& R50, 001 to R100, 000: $17(15.74 \%)$ \\
& R100, 001 or more: $8(7.41 \%)$ \\
Marketing strategies used for selling or promoting & Word of mouth: $38(35.19 \%)$ \\
items on promotion or sale & Leaflets: $34(31.48 \%)$ \\
& Posters: $21(19.44 \%)$ \\
& Newspaper adverts: $7(6.48 \%)$ \\
& Radio adverts: $2(1.85 \%)$ \\
& TV adverts: $1(0.93 \%)$ \\
Others: $5(4.63 \%)$
\end{tabular}

Marketing skills are assessed in Table 3. The assessment was done by using standards set out by Mooradian, Matzler and Ring (2012:45). It can be seen from the table that 63 of the 108 respondents (58.33\%) were capable of marketing goods and services adequately by the standards of Mooradian, Matzler and Ring (2012), whereas the remaining 45 respondents $(41.67 \%)$ were incapable of doing the same by the same standards. According to Kotler and Keller (2012), effective marketing consists of the set of actions or tactics that are used by entrepreneurs in order to promote products, goods and services in the marketplace by using the four Ps (Price, Product, Promotion and Place). About $88 \%$ of entrepreneurs were capable of setting the right price of goods to customers (First P). About $87 \%$ of entrepreneurs were capable of offering the right product to customers (Second P). About 79\% of entrepreneurs were capable of promoting the right product to customers (Third P). About $81 \%$ of entrepreneurs were capable of selling goods at the right place to customers (Fourth P). Results reported in Table 2 are fairly similar to results reported by Charman, Petersen, Piper, Lindeman and Legg (2017).

Table 3: Assessment of Marketing Ability of Entrepreneurs ( $n=108)$

\begin{tabular}{ll}
\hline Variable of study & Percentage \\
\hline Overall ability to market goods & Adequate: $63(58.33 \%)$ \\
& Inadequate: $45(41.67 \%)$
\end{tabular}

Ability in setting the right price of goods to customersGood: 15 (13.89\%)

(First P)

Above average: 48 (44.44\%)

Average: $32(29.63 \%)$

Below average: $9(8.33 \%)$

Poor: $4(3.70 \%)$

Ability in offering the right product to customersGood: $14(12.96 \%)$

(Second P)

Above average: 47 (43.52\%)

Average: 33 (30.56\%)

Below average: 7 (6.48\%)

Poor: 7 (6.48\%) 
Ability in promoting the right product (Third P)

Ability in selling goods at the right place (Fourth P)
Good: 18 (16.67\%)

Above average: 41 (37.96\%)

Average: 27 (25.00\%)

Below average: 5 (4.63\%)

Poor: 17 (15.74\%)

Good: 16 (14.81\%)

Above average: 43 (39.81\%)

Average: 28 (25.93\%)

Below average: 7 (6.48\%)

Poor: 14 (12.96\%)

Table 4 shows frequency counts and percentages for factors that are taken into consideration for setting the selling price of discounted items by the 108 entrepreneurs who were selected for the study. The table shows that the demand for products, goods and services accounts for about $25 \%$ of all such considerations. The second key factor is the need for enough cash flow (22\%). Charman, Petersen, Piper, Lindeman and Legg (2017) have found similar results about start-up SMMEs in developing nations.

Table 4: Factors that Affect the Selling Price of Discounted Items (n=108)

\begin{tabular}{ll}
\hline Factors considered for setting the selling price of discounted items & Frequency (Percentage) \\
\hline Demand for products, goods and services & $27(25.00 \%)$ \\
Need for enough cash flow & $24(22.22 \%)$ \\
Pressure from business rivals at the marketplace & $13(12.04 \%)$ \\
The quality of products, goods and services & $11(10.19 \%)$ \\
The purchase price and the cost of goods and services & $10(9.26 \%)$ \\
Bulk price & $8(7.41 \%)$ \\
Need to clear up stock and free up space & $6(5.56 \%)$ \\
Need to place fresh order & $4(3.70 \%)$ \\
Affordability of products, goods and services & $3(2.78 \%)$ \\
Other reasons & $2(1.85 \%)$ \\
\hline
\end{tabular}

Factors that were significantly associated with the ability of entrepreneurs to market their products effectively were identified by using two-by-two crosstab associations (Mertler and Reinhart, 2016). Values of the dependent variable of study, Y (Ability to market products effectively) were defined as follows:

Ability to market products effectively $=\left\{\begin{array}{l}1 \text { if adequate } \\ 2 \text { if inadequate }\end{array}\right.$

It can be seen from Table 5 that all 6 variables listed in the table are significantly associated with the dependent variable of study at the $5 \%$ level of significance. These predictor variables were the ability to order goods and merchandise in bulk on credit, the ability to order goods and merchandise in bulk on credit, the ability to raise loan from money-lending institutions, the ability to network with wholesale suppliers and retailers, the ability to raise start-up capital from family or personal savings, the duration of business operation, and access to training opportunities, in a decreasing order of strength. 
Table 5: Significant Two-By-Two Associations $(\mathrm{n}=108)$

\begin{tabular}{lcc}
\hline $\begin{array}{l}\text { Factors Significantly Associated with Ability to market Pearson's chi-Square Statistic } \\
\text { products Effectively }\end{array}$ & P \\
\hline Access to credit facility for ordering stock & 9.5588 & 0.000 \\
Access to loan facility from money lenders & 9.1204 & 0.000 \\
& & 0.000 \\
Ability to network with wholesale suppliers and retailers & 8.7455 & 0.001 \\
Ability to raise start-up capital from family or personal savings & 6.2286 & 0.002 \\
Lengthy experience in entrepreneurship & 4.6723 & 0.003 \\
\hline
\end{tabular}

Table 6 shows a comparison between 2 categories of entrepreneurs with regards to the ability to market products effectively by the standards Mooradian, Matzler and Ring (2012) and Kotler and Keller (2012). Category 1 consists of 63 entrepreneurs (58.33\%) who possess adequate marketing skills, whereas Category 2 consists of 45 entrepreneurs (41.67\%) who lack marketing skills. In light of research findings reported above, it could be concluded that there is a pressing need for promoting awareness about basic marketing skills and strategies in South African townships. Start-up SMMEs in Alexandra Township is characterised by an inability to effectively utilise and benefit from valuable marketing strategies that have produced tangible results elsewhere in South Africa. As such, it would be prudent and strategically beneficial for the South African Small Enterprise Development Agency (SEDA) to educate novice entrepreneurs in South African townships on areas such as basic marketing strategies, the preparation of business plans, networking auditing and basic accounting skills.

Table 6: Comparison with Regards to Marketing Skills $(n=108)$

\begin{tabular}{|c|c|c|}
\hline \multicolumn{2}{|c|}{$\begin{array}{l}\text { Factors Significantly Associated with Marketing Adequate (n1=63) } \\
\text { Skills }\end{array}$} & \multirow{2}{*}{$\begin{array}{l}\text { Inadequate }(\mathbf{n} \mathbf{2}=\mathbf{4 5}) \\
\text { Yes: } 8 \% \\
\text { No: } 15 \%\end{array}$} \\
\hline Access to credit facility for ordering stock & $\begin{array}{l}\text { Yes: } 72 \% \\
\text { No: } 5 \%\end{array}$ & \\
\hline Access to loan facility from money lenders & $\begin{array}{l}\text { Yes: } 72 \% \\
\text { No: } 5 \%\end{array}$ & $\begin{array}{l}\text { Yes: } 8 \% \\
\text { No: } 15 \%\end{array}$ \\
\hline $\begin{array}{l}\text { Ability to network with wholesale supplie } \\
\text { retailers }\end{array}$ & $\begin{array}{l}\text { dYes: } 73 \% \\
\text { No: } 4 \%\end{array}$ & $\begin{array}{l}\text { Yes: } 15 \% \\
\text { No: } 8 \%\end{array}$ \\
\hline $\begin{array}{l}\text { Ability to raise start-up capital from } \\
\text { members or personal savings }\end{array}$ & $\begin{array}{l}\text { yYes: } 70 \% \\
\text { No: } 7 \%\end{array}$ & $\begin{array}{l}\text { Yes: } 16 \% \\
\text { No: } 7 \%\end{array}$ \\
\hline Long duration of business operation & $\begin{array}{l}\text { Yes: } 70 \% \\
\text { No: } 7 \%\end{array}$ & $\begin{array}{l}\text { Yes: } 16 \% \\
\text { No: } 7 \%\end{array}$ \\
\hline Access to training opportunities & $\begin{array}{l}\text { Yes: } 57 \% \\
\text { No: } 20 \%\end{array}$ & $\begin{array}{l}\text { Yes: } 11 \% \\
\text { No: } 12 \%\end{array}$ \\
\hline
\end{tabular}

As has been reported by Fatoki (2014) and Chimucheka (2014), entrepreneurs with adequate marketing skills differ significantly from those with inadequate marketing skills on the basis of all six variables of comparison. Table 7 shows estimates obtained from ordered logit analysis (Agresti, 2016). 
Table 7: Estimates from Ordered Logit Analysis $(\mathrm{n}=108)$

\begin{tabular}{|c|c|c|c|}
\hline Variable & P-value & Odds Ratio & $\begin{array}{l}\text { 95\% Confidence Intervals of Odds } \\
\text { Ratio }\end{array}$ \\
\hline $\begin{array}{l}\text { Access to credit facility for } \\
\text { ordering stock }\end{array}$ & 0.000 & 3.74 & $(1.73$ \\
\hline $\begin{array}{l}\text { Ability to raise loan from } \\
\text { money-lending } \\
\text { institutions }\end{array}$ & 0.000 & 3.27 & (1.57, \\
\hline $\begin{array}{l}\text { Ability to network with } \\
\text { wholesale suppliers and } \\
\text { retailers }\end{array}$ & 0.000 & 2.88 & $(1.43$, \\
\hline
\end{tabular}

Table 7 shows that marketing ability is significantly influenced by 3 predictor variables. These 3 predictor variables of the study were the ability to order goods and merchandise in bulk on credit, ability to raise a loan from money-lending institutions, and ability to network with wholesale suppliers and retailers, in decreasing order of strength. These findings are quite similar to similar findings that have been reported about start-up SMMEs in South African townships and cities by Fatoki (2014), Chimucheka (2014), Akos-Rona and Sagi (2015) and Charman, Petersen, Piper, Lindeman and Legg (2017).

Table 8 shows estimates obtained from the Bayesian analysis. Logit analysis produced estimates based on odds ratios or $\exp (\beta)$. By contrast, MCMC algorithms produced estimates based on the regression coefficient $\beta$. Both methods of estimation (logit and Bayesian analysis) produced similar findings.

Table 8: Estimates from MCMC Algorithms

\begin{tabular}{lllll}
\hline Marketing Ability & $\hat{\beta}$ & P-value & 95\% C. I. for $\hat{\beta}$ \\
\hline Access to credit facility for ordering stock & 1.32 & 0.000 & $(0.55,1.96)$ \\
Ability to raise loan from money-lending institutions & 1.18 & 0.000 & $(0.45,1.90)$ \\
Ability to network with wholesale suppliers and retailers & 1.06 & 0.000 & $(0.36,1.68)$ \\
\hline
\end{tabular}

\section{Conclusion and Recommendations}

The research was aimed at determining the suitability and adequacy of marketing tactics and strategies used by SMMEs that operate in the Alexandra Township based on standards set out by Mooradian, Matzler and Ring (2012) and Kotler and Keller (2012). The study has assessed the extent to which entrepreneurs who conducted footwear and textile businesses at Alexandra Township used the four Ps of marketing (Price, Product, Promotion, and Place) in the course of marketing their products to customers. The study found that about 58\% of entrepreneurs were capable of marketing their goods and services effectively, whereas the remaining $42 \%$ were incapable of marketing their products effectively. The ability of entrepreneurs to market goods and services effectively was significantly influenced by access to credit facility for ordering stock in large quantity from wholesale distributors, the ability to raise loan from money-lending institutions, and the ability to network with wholesale suppliers and retailers. This recommendation is in line with the key mandate of the South African National Department of Small Enterprise Development Agency (Thompson, 2016). 


\section{References}

Agresti, A. (2016). Building and Applying Logistic Regression Models. New York: John Wiley \& Sons.

Akos-Rona, T. \& Sagi, M. (2015). Entrepreneurship and Self-Employment in Transition Economies. Entrepreneurship, 2(1), 27-31.

Aparicio, S., Urbano, D. \& Audretsch, D. (2016). Institutional factors, opportunity entrepreneurship and economic growth: Panel data evidence. Technological Forecasting and Social Change, 102(1), 45-61.

Bernier, C. (2015). The impact of size and of institutional mechanisms. Industrial Relations, 60(3), 540-565.

Callaghan, C. \& Venter, R. (2011). An investigation of the entrepreneurial orientation, context and entrepreneurial performance of inner-city Johannesburg street traders. Southern African Business Review, 15(1), 46-62.

Charman, A. J., Petersen, L. M., Piper, L. E., Lindeman, R. \& Legg, T. (2017). Small area census approach to measure the township informal economy in South Africa. Journal of Mixed Methods Research, 11(1), 36-58.

Chimucheka, T. (2014). Entrepreneurship education in South Africa. Mediterranean Journal of Social Sciences, 5(2), 403.

Chow, S. C., Shao, J., Wang, H. \& Lokhnygina, Y. (2017). Sample size calculations in clinical research. New York: Chapman and Hall/CRC.

Dagut, S. (2017). Analyzing red tape constraints and regulatory costs for small enterprises. Annual Business Summit. Pretoria: Department of Trade and Industry.

Fatoki, 0. (2014). The causes of the failure of new small and medium enterprises in South Africa. Mediterranean Journal of Social Sciences, 5(20), 922.

Gauteng Provincial Legislature (2017). 2015-2016 Annual report and citizens' reports. Retrieved 27 October 2018, from http://gpl.gov.za/2015-2016-annual-reports/

George, G., Corbishley, C., Khayesi, J. N., Haas, M. R. \& Tihanyi, L. (2016). Bringing Africa in: Promising directions for management research. London: Oxford.

Jurgens, U. \& Donaldson, R. (2012). A Review of literature on transformation processes in South African townships. Journal of Urban Forum, 23(1), 23-42.

Jutla, D., Bodorick, P. \& Dhaliwal, J. (2012). Supporting the E-Readiness of small and medium-sized enterprises: Approaches and metrics. Internet Research: Electronics Networking Application and Policy, 2(1), 13-24.

Jamali, D., Lund-Thomsen, P. \& Jeppesen, S. (2017). SMEs and CSR in developing countries. Business \& Society, 56(1), 11-22.

Kline, P. (2015). A handbook of test construction (psychology revivals): introduction to psychometric design. New York: Routledge.

Kotler, P. \& Keller, L. K. (2012). Marketing Management, 14th edition. New York: Pearson Education Limited.

Kulkarni, V. G. (2016). Modelling and analysis of stochastic systems. New York: Chapman and Hall/CRC.

Leigh, N. G. \& Blakely. (2016). Planning local economic development: Theory and practice. London: SAGE publications.

Lewis, C. A. \& Loewenthal, K. (2015). An introduction to psychological tests and scales. New York: Psychology Press.

Marivate, S. P. (2014). The relationship between growth in small businesses and cash flow: A study of small businesses in Tshwane. European Journal of Research and Reflection in Management Sciences, 2(2), 19-36.

Martinez, J. A. \& Martinez, L. (2010). Some insights on conceptualizing and measuring service quality. Journal of Retailing and Consumer Services, 17(1), 29-42.

Mertler, C. A. \& Reinhart, R. V. (2016). Advanced and multivariate statistical methods: Practical application and interpretation. New York: Routledge.

Moraru, L. (2012). Academic internal stakeholder condition: A comparative approach. Procedia-Social and Behavioral Sciences, 69(1), 54-72.

Mooradian, T. A., Matzler, K. \& Ring, L. J. (2012). Strategic Marketing. Upper Saddle River, New Jersey: Prentice Hall. 
Narang, R. (2012). How do management students perceive the quality of education in public institutions? Quality Assurance in Education, 20(4), 357-371.

Ogunnaike, 0. \& Olaleke, O. (2010). Assessing the relationship between service quality and customer satisfaction; evidence from the Nigerian banking industry. Global Journal of Management and Business Research, 10(3), 2-5.

Racela, O. C. (2014). Customer Orientation innovation competencies and firm performance: A proposed conceptual model. Procedia Social and Behavioral Sciences, 1(2), 13-19.

Thompson, D. K. (2016). Risky business and geographies of refugee capitalism in the Somali migrant economy of Gauteng, South Africa. Journal of Ethnic and Migration Studies, 42(1), 120-135.

Stam, E. (2015). Entrepreneurial ecosystems and regional policy: A sympathetic critique. European Planning Studies, 23(9), 1759-1769.

Statistics South Africa. (2012). Business register 2015/2016. Pretoria: Statistics South Africa.

Worku, Z. (2016). Barriers to the growth of small, micro and medium-sized business enterprises in the Vaal Triangle region of South Africa. African Journal of Science, Technology, Innovation and Development, 8(2), 134-141.

Zineldine, M. \& Phillipson, S. (2012). Kotler and Borden are not dead: the myth of relationship marketing and truth of the 4Ps. Journal of Consumer Marketing, 24(4), 231-232. 